\title{
Prioritisation of barriers for supply chain management implementation in the Malaysian automotive industry
}

\author{
Azilah Anis ${ }^{\mathrm{a}}$ (D), Rafikul lslam ${ }^{\mathrm{b} *}$ (D), Nor Intan Adha Hafit ${ }^{\mathrm{a}}$ \\ a Universiti Teknologi MARA, Faculty of Business and Management, Puncak Alam, Selangor, Malaysia \\ ${ }^{\mathrm{b}}$ International Islamic University Malaysia, Department of Business Administration, Kuala Lumpur, Malaysia. \\ *rislam@iium.edu.my
}

\begin{abstract}
Paper aims: Several Barriers impede the robust effectiveness of the supply-chain management implementation for the Malaysian automotive industry. The purpose of the present work is to identify these Barriers and prioritize them.

Originality:Originality of the present work lies in identifying the Barriers, putting them into categories and subsequently prioritize them by applying a scientific method such as Analytic Hierarchy Process (AHP).Research

Research method:This study has identified five main categories of Barriers through literature reviews. Fourteen practitioners who are involved with the automotive industry helped prioritise those Barriers by applying the AHP.Main

Main findings: Five main categories of Barriers are found to be technological, organisational, individual, strategic, and cultural barriers. Organisational barrier is the most critical barrier followed by technological and strategic barriers.

Implications for theory and practice: This research provides important feedback to the automotive company managers to take appropriate measures to minimise negative impacts of the barriers identified.
\end{abstract}

\section{Keywords}

Supply chain management. Barriers. Automotive industry. Analytic hierarchy process.

How to cite this article: Anis, A., 1slam, R., \& Hafit, N. 1. A. (2022). Prioritisation of barriers for supply chain management implementation in the Malaysian automotive industry. Production, 32, e20210073. https://doi.org/10.1590/01036513.20210073

Received: June 09, 2021; Accepted: Dec. 20, 2021

\section{Introduction}

Supply Chain (SC) consists of all activities, functions and facilities in transforming raw materials to an end product or service (Chopra \& Meindl, 2007). Traditionally, it starts from suppliers and ends at customers. Then over the years, parties that are involved in SC have been expanded to five groups: supplier, manufacturer, distributor, retailer, and customer (Parmar \& Shah, 2016). On the other hand, Supply Chain Management (SCM) is a management of all supply chain activities ranging from financial aspect, information, materials to products. The management needs to ensure a smooth flow of movement for a product or service from supplier to customer (Chopra \& Meindl, 2007). In addition, an effective implementation of SCM enables reduction in inventory, improves information sharing, increases mutual trust among supply chain partners, reduces product life cycle and ultimately increases customer satisfaction (Lee et al., 2011). Due to these benefits, most organisations have invested significant amount of money in strengthening their SCM activities.

Most organisations are aware about the challenges and barriers to implement an effective SCM. These barriers exist in many forms and many researchers have categorised them as internal and external barriers (lslam \& Anis, 2018; Adhikari, 2010; Bhat \& Rajashekhar, 2009; Sadi \& Al-Dubaisi, 2008). Lack of top management support, lack of employee empowerment and training, lack of financial resources as well as poor information technology are some of the barriers that are listed as internal barriers. On the other hand, resistance to sharing 
information, lack of collaboration and mistrust among supply chain partners are barriers that are classified as external barriers (Sadi \& Al-Dubaisi, 2008; Bhat \& Rajashekhar, 2009). Nevertheless, only few researchers have taken initiatives to group the barriers into a specific category which can be found in the work of Parmar and Shah, 2016; Gorane and Kant, 2015 as well as Fawcett et al., 2015. Technological barrier, organisational barrier, individual barrier, cultural barrier are some categories identified by these researchers. These categories are important to assist organisations in identifying the barriers and addressing them based on the identified category. Furthermore, limited studies have been carried out to empirically rank these identified categories, specifically in the context of the Malaysian automotive industry.

Thus, this study aims to rank the list of Barriers as well as Sub-Barriers for effective SCM implementation in the Malaysian automotive industry. The ranking or prioritised list is finally obtained by applying one of the well-known decision-making methods used in SCM, namely the Analytic Hierarchy Process (AHP).

\section{The automotive industry in Malaysia}

Automotive industry in Malaysia comprises more than 25 producers and assembly plants as well as over 650 component manufacturers (Malaysian Automotive Association, 2021). The first Malaysian automobile company named PROTON was established in 1993 followed by the second automobile company called PERODUA in 1994. Since then, the automotive industry has become one of the main contributors to the Malaysian economy. For instance, it had contributed 4.2\% or RM40 billion in 2019 and is expected to contribute RM104.2 billion to the nation's GDP by 2030 (www.theedgemarkets.com). In 2020, 485,186 units of automobiles were manufactured and assembled that included 457,755 passenger cars and 27,431 commercial vehicles (www.maa.org.my). Due to this achievement, Malaysia is reported as the third largest automobile producer in Southeast Asia after Thailand and Indonesia. It is also acknowledged that the Malaysia's automotive industry has employed over 700,000 staff.

In fact, the achievement of Malaysia's automotive industry had attracted researchers to investigate relevant areas within the industry. For instance, works in the following research areas are worth mentioning like Quality Practices (Habidin et al., 2018; Habidin \& Mohd Yusof, 2013; Mohd et al., 2011), Accounting and Costing (Baharudin \& Jusoh, 2019) and Business Strategies (Nazir \& Shavarebi, 2019).

Meanwhile, several other studies have also been discovered from literature that discussed issues of the SCM in the Malaysian automotive industry. For instance, some researchers had taken initiatives to investigate issues related to the Green SCM in the Malaysian automotive companies (Fernando et al., 2018). Other researchers are more interested to study the issue on the supply chain from the supplier's perspective in the Malaysia's automotive companies. These areas include the Supply Chain Adaptability and Performance (Feizabadi \& Alibakhshi, 2021), and Supply Chain Technology Adoption (Kamaruddin \& Udin, 2009).

Even though these works seem to be related to SCM but studies on the Barriers for effective SCM implementation in the Malaysian automotive industry are hardly found in previous researches. Since Barriers in automotive SCM implementation is not thoroughly investigated by researchers, especially in the context of Malaysia, hence the present study intends to fill up this research gap.

\subsection{Barriers in the supply chain}

SCM encompasses the planning and management of all activities ranging from sourcing and procurement, conversion of raw materials to end products as well as logistics management activities. Furthermore, it includes coordination and collaboration with channel partners who are suppliers, intermediaries, third party service providers as well as customers (Chopra \& Meindl, 2010). Zhang \& Wu (2013) stress that effective implementation of SCM is an indispensable act. This is because of three reasons i.e. 1) it can reduce transactional costs 2) it can control and facilitate information sharing and 3) maintain its market sensitivity.

A research found that despite generating substantial benefits and proving the importance of effective SCM, companies still continue to encounter barriers that are preventing them from implementing effective SCM (Meehan \& Muir, 2008). These barriers are complex and require adoption of appropriate strategies so that problems can be timely resolved (Ravi et al., 2005). As mentioned previously, some researchers have grouped the barriers into two categories namely internal and external barriers (1slam \& Anis, 2018; Adhikari, 2010; Bhat \& Rajashekhar, 2009; Sadi \& Al-Dubaisi, 2008).

In addition, some researchers have grouped the barriers into several specific categories. For example, Parmar \& Shah (2016) categorised the barriers into five groups which are strategic, cultural, technological, individual, and organisational. These categories of Barriers are then further elaborated with their corresponding Sub-Barriers (refer to Table 1). 
Gorane \& Kant (2015) have grouped the barriers into managerial, technological, financial, organisational, and collaborative barriers (refer to Table 2). However, they did not specifically categorise the barriers into the identified categories. Fawcett et al. (2015), on the other hand, have named the classified barriers as structural resistors, sociological resistors, organisational routines, and individual skills.

The present study used the barriers that were categorised by Parmar \& Shah (2016). Barriers from these authors were selected due to their extensive reviews on barriers in SCM. Parmar \& Shah (2016) initially compiled 33 barriers identified by other researchers ranging from the Supply Chain Performance, Green Supply Chain, Humanitarian Supply Chain, Adoption of IT in Supply Chain, Strategic Supply Chain, Quality Management in

Table 1. Supply Chain Management Barriers and Sub-Barriers.

\begin{tabular}{|c|c|c|}
\hline No. & Category & Supply Chain Management Barriers \\
\hline \multirow[t]{7}{*}{1} & Strategic barrier $(\mathrm{Cl})$ & Unclear organisational objective (C11) \\
\hline & & Lack of top management commitment and support $(\mathrm{C} 12)$ \\
\hline & & Low customer satisfaction index ( $\mathrm{C} 13)$ \\
\hline & & Lack of awareness about SCM (C14) \\
\hline & & Short-term decision-making perspectives ( $\mathrm{C} 15)$ \\
\hline & & Political instability (C16) \\
\hline & & Lack of resources and capability ( $\mathrm{C} 17)$ \\
\hline \multirow[t]{3}{*}{2.} & Cultural barrier (C2) & Unwillingness to implement supply chain practices (C21) \\
\hline & & Unwillingness to share information among supply chain partners (C22) \\
\hline & & Mistrust among employees and supply chain partners (C23) \\
\hline \multirow[t]{2}{*}{3.} & Technological barrier (C3) & Lack of information technology (C31) \\
\hline & & Poor 1CT structure (C32) \\
\hline \multirow[t]{6}{*}{4.} & Individual barrier $(C 4)$ & Lack of education of employee and suppliers' employee (C41) \\
\hline & & Resistance to change ( $\mathrm{C} 42)$ \\
\hline & & Lack of motivation and employee involvement (C43) \\
\hline & & Unawareness among society about social practices (C44) \\
\hline & & Lack of awareness about environment and other sustainability issues (C45) \\
\hline & & Lack of necessary tools, management skills and knowledge ( $\mathrm{C} 46)$ \\
\hline \multirow[t]{6}{*}{5.} & Organisational barrier $(\mathrm{C} 5)$ & Lack of financial gain (C51) \\
\hline & & Lack of framework (C52) \\
\hline & & Lack of measurement system (C53) \\
\hline & & Lack of proper organisational structure to create and share knowledge (C54) \\
\hline & & $\begin{array}{l}\text { Lack of inter-organisational cooperation and coordination } \\
\qquad \text { (C55) }\end{array}$ \\
\hline & & Lack of infrastructure (C56) \\
\hline
\end{tabular}

Source: Parmar \& Shah (2016).

Table 2. Supply Chain Management Barriers from previous literature.

\begin{tabular}{cc}
\hline No. & Supply Chain Management Barriers \\
\hline 1. & Lack of top management commitment and support \\
2. & Unclear organisational objective \\
3. & Resistance to change \\
4. & Lack of motivation and employee empowerment \\
5. & Poor corporate culture \\
6. & Mistrust among employee and Supply Chain (SC) partners \\
7. & Lack of education and training to employee and supplier \\
8. & Poor lnformation and Communication Technology (1CT) infrastructure \\
9. & Lack of financial resources \\
10. & Unwillingness to implement SC practices \\
11. & Lack of integration among SC partners \\
12. & Lack of collaboration among SC partners \\
13. & Lnwillingness to share information among SC partners \\
14. & Lack of responsiveness \\
15. & Lack of customer satisfaction index \\
\hline Sor & \\
\hline
\end{tabular}

Source: Gorane \& Kant (2015). 
Supply Chain, Customer Relationship in Supply Chain to Knowledge Management. These barriers are then grouped into five clusters, namely 1) strategic barrier, 2) cultural barrier, 3) technological barrier, 4) individual barrier, and 5) organisational barrier. Moreover, these five categories of Barriers are further divided into Sub-Barriers as has been shown in Table 1. This enables the respondents of the present study to comprehend the content for each identified Barrier more clearly.

For automotive industry, limited studies have been found to investigate the barriers in SCM implementation. It is found that most researchers are interested to investigate barriers of the Green Supply Chain Management as underlined by Flavia et al. (2017), Balon et al. (2016) and Drohomeretski et al. (2014). Charan et al. (2009) on the other hand, have investigated the barriers in performance measurement system implementation in the Indian Automotive Industry. This study focuses on barriers in the automotive SCM implementation in the automotive industry of Malaysia.

\subsection{Applications of AHP in supply chain management}

Analytic Hierarchy Process (AHP) is a decision-making method which was developed in 1970's by Thomas $\mathrm{L}$. Saaty while he was working in the Department of Defence and the National Science Foundation of the United States. Since then, AHP has been applied in various areas and industries to facilitate decision making process.

The acceptance of AHP as a managerial decision-making method can also be seen in SCM area. The first application of AHP was observed in 1993 and since then its applications increased drastically as demonstrated by Figure 1 (Tramarico et al., 2015).

Tramarico et al. (2015) categorised the applications of AHP in SCM into five main clusters of which the most prominent one is supplier or vendor selection. In fact, Masella \& Rangone (2000) maintain that supplier or vendor selection is the pioneering area where AHP was applied. The emphasis of Masella \& Rangone (2000) is supported with a review of AHP applications in vendor and supplier selection conducted by Aouadni et al. (2019) and Tahiri et al. (2008). One of the latest researches in supplier selection by Agrawal \& Kant (2020) has also applied Fuzzy AHP in their work.

The Green Supply Chain which is rated second is another cluster where AHP has been applied substantially. For instance, recent work on the Green Supply Chain can be seen in the work of Zhou et al. (2019) and Mastrocinque et al. (2020). The third cluster consists of Supply Chain Development, Performance Measurement, Value Chain and Supplier Collaboration (Korpela et al., 2001). Supply Chain Distribution Network, Warehouse Location and Customer Service are grouped into the fourth cluster (Korpela \& Lehmusvaara, 1999). Lastly, Tramarico et al. (2015) grouped Supplier Distribution Centre Network, Supply Chain Integration and Collaborative Planning, Forecasting and Replenishment in the fifth and final cluster where AHP has been applied.

Few studies have been found to compile the applications of AHP in SCM. In addition to the previously mentioned work by Tramarico et al. (2015), Lima-Junior \& Carpinetti (2017) critically reviewed one of the important aspects in SCM, namely supply chain performance evaluation. The authors reviewed 84 papers from



Figure 1. The application of AHP and other multi-criteria decision making methods in SCM. Source: Tramarico et al. (2015). 
Science Direct, Scopus, Emerald Insight and IEEE Explorer as well as Google Scholar. They study discovered that AHP and DEA are the most used techniques, either in single or combined applications in evaluating supplier performance.

The applications of AHP in various areas of SCM have shown what a significant role AHP can play in making decisions in the area of SCM. Taking this as cognizance, the researchers of this study have applied AHP to rank SCM Barriers in the context of the Malaysian automotive industry.

\section{Research methodology}

The present study adopted a quantitative approach. The steps employed are described below:

a) The five categories of Barriers from Parmar \& Shah (2016), namely 1) Strategic barrier, 2) Cultural barrier, 3) Technological barrier, 4) Individual barrier and 5) Organisational barrier are considered for prioritisation. Further, the categories were divided into Sub-Barriers (See Table 1).

b) The five identified categories of Barriers and their Sub-Barriers were then validated by the esteemed practitioners who have vast experiences on the supply chain implementation in the automotive industry.

c) Next, these categories of Barriers were used to construct the AHP survey questionnaire. The sample of the AHP questionnaire given to the practitioners for the five identified Barriers is shown in Figure 2.

\section{SECTION B: SCM BARRIERS}

For the statement below, please compare the relative SEVERITY with respect to: objective which is prioritisation of barriers for supply chain implementation in automotive companies. CHOOSE and CIRCLE ONLY ONE NUMBER by using the following scale:

\section{List of Barriers:}

1. Strategic barrier : barriers that are related to identification of long term or overall aims and interest

2. Cultural barrier: barriers that are related to the ideas, practices and behaviour

3. Technological barrier : barriers that are related to or using technology

4. Individual barrier : barriers that are related to characteristic of a particular employee/ person

5. Organisational barrier : barriers that are related to an organisation or the way it is set up

1= EQUAL 3=MODERATELYMORE 5=STRONGLY MORE 7=VERY STRONGLY MORE 9=EXTREMELY MORE

\begin{tabular}{|c|l|c|c|c|c|c|c|c|c|c|c|c|c|c|c|c|c|c|l|}
\hline 1. & Strategic barrier & 9 & 8 & 7 & 6 & 5 & 4 & 3 & 2 & 1 & 2 & 3 & 4 & 5 & 6 & 7 & 8 & 9 & Cultural barrier \\
\hline 2. & Strategic barrier & 9 & 8 & 7 & 6 & 5 & 4 & 3 & 2 & 1 & 2 & 3 & 4 & 5 & 6 & 7 & 8 & 9 & Technological barrier \\
\hline 3. & Strategic barrier & 9 & 8 & 7 & 6 & 5 & 4 & 3 & 2 & 1 & 2 & 3 & 4 & 5 & 6 & 7 & 8 & 9 & Individual barrier \\
\hline 4. & Strategic barrier & 9 & 8 & 7 & 6 & 5 & 4 & 3 & 2 & 1 & 2 & 3 & 4 & 5 & 6 & 7 & 8 & 9 & Organisational barrier \\
\hline 5. & Cultural barrier & 9 & 8 & 7 & 6 & 5 & 4 & 3 & 2 & 1 & 2 & 3 & 4 & 5 & 6 & 7 & 8 & 9 & Technological barrier \\
\hline 6. & Cultural barrier & 9 & 8 & 7 & 6 & 5 & 4 & 3 & 2 & 1 & 2 & 3 & 4 & 5 & 6 & 7 & 8 & 9 & Individual barrier \\
\hline 7. & Cultural barrier & 9 & 8 & 7 & 6 & 5 & 4 & 3 & 2 & 1 & 2 & 3 & 4 & 5 & 6 & 7 & 8 & 9 & Organisational barrier \\
\hline 8. & Technological barrier & 9 & 8 & 7 & 6 & 5 & 4 & 3 & 2 & 1 & 2 & 3 & 4 & 5 & 6 & 7 & 8 & 9 & Individual barrier \\
\hline 9. & Technological barrier & 9 & 8 & 7 & 6 & 5 & 4 & 3 & 2 & 1 & 2 & 3 & 4 & 5 & 6 & 7 & 8 & 9 & Organisational barrier \\
\hline 10. & Individual barrier & 9 & 8 & 7 & 6 & 5 & 4 & 3 & 2 & 1 & 2 & 3 & 4 & 5 & 6 & 7 & 8 & 9 & Organisational barrier \\
\hline
\end{tabular}

Figure 2. Sample AHP survey questionnaire. 
d) Structured interviews were conducted to collect AHP data from the 14 practitioners from local and foreign automotive companies who are involved in the automotive industry. The Purposive Sampling Technique was adopted in selecting these practitioners. The main criteria decided to be adopted to select the practitioners was that they should possess a minimum Bachelor Degree qualification and have more than 10 years of working experience.

e) Subsequently, the AHP method was applied in three stages as suggested by Saaty (1990) in prioritising the five identified category of Barriers and the Sub-Barriers. They are as follows:

- Structuring the AHP Hierarchy.

AHP hierarchy is a tree-like diagram that consists of several levels. The first level represents the goal of the problem; the goal of the present study is to prioritise the Barriers of SCM implementation in the Malaysian automotive industry. The second level shows the criteria or the five identified categories of Barriers followed by the third level which represents the sub-criteria or the Sub-Barriers for each identified Barrier. Figure 3 exhibits the general form of a AHP hierarchy.

- Constructing Pair-Wise Comparison Matrices:

Each element at an upper level of the hierarchy was used to compare the elements in the level immediately below it. A Pair-Wise Comparison Matrix $(n \times n)$ was constructed for lower level elements with respect to the one in the level immediately above. The Pair-Wise Comparison Matrix A, in which element $\mathrm{a}_{\mathrm{ij}}$ of the matrix represents the relative importance of the $\mathrm{i}^{\text {th }}$ factor with respect to the $\mathrm{j}^{\text {th }}$ factor. The general form of a pair-wise comparison matrix is as follows:

$$
A=\left(a_{i j}\right)=\left[\begin{array}{cccc}
a_{11} & a_{12} & \ldots & a_{1 n} \\
a_{21} & a_{22} & \ldots & a_{2 n} \\
\ldots & \ldots . & \ldots & \ldots \\
a_{n 1} & a_{n 2} & \ldots & a_{n n}
\end{array}\right](i, j=1,2, \ldots n)
$$

The pair-wise comparisons generate a matrix of relative priorities for each level of the hierarchy. The number of matrices depends on the number of elements at each level. The order of the matrix at each level depends on the

\section{Goal \\ Objects/ Criteria}

\section{Sub objects/ Sub criteria}

Alternatives

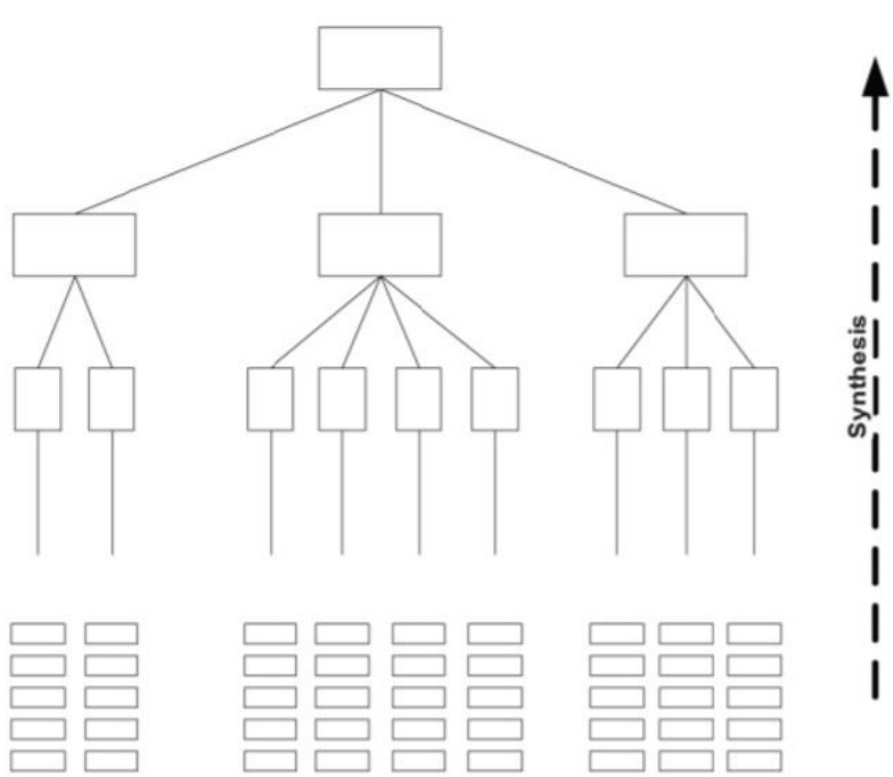

Figure 3. AHP hierarchy. Source: Tsinidou et al. (2010). 
number of elements at the lower level that it links to. In terms of judgments, there are $n(n-1) / 2$ judgments that need to be made for a matrix of size $n \times n$.

- Synthesizing the Priorities:

The priorities obtained from the comparisons for the elements belonging to a level of the hierarchy should be weighed with respect to the priority of the element belonging to the immediately above level and with respect to which the comparisons are made. This process of weighing and adding continues until the final priorities of the elements in the lowest level are obtained. At the same time, Consistency Ratio (CR) of the Pair-Wise Comparison Matrix for all levels of the hierarchy are then computed. Saaty (1980) asserts that the CR should be less than 0.10 for acceptable judgements.

\subsection{Group judgement}

Using the AHP questionnaire, each of the 14 practitioners was requested to provide his or her own judgements for the prioritisation of the barriers for SCM implementation. Seeking consensus for all the comparisons was not the objective; therefore, the respondents were free to provide their own judgments. Data from the AHP questionnaires were then transformed into their individual comparison matrices. Then, the individual Pair-Wise Comparison Matrices were compiled to form a group of Pair-Wise Comparison Matrix for each level of hierarchy i.e., level 2 and level 3. Each entry in the individual Pair-Wise Comparison Matrix was aggregated by using the Geometric Mean (Krejčí \& Stoklasa, 2018; Islam, 2010). Geometric Mean calculation was applied to determine the respective entries in the group Pair-Wise Comparison Matrices for all the five categories (Parmar \& Shah, 2016) of Barriers as well as their corresponding Sub-Barriers.

\section{Results and discussion}

The demographic details of the 14 practitioners who took part in the survey are provided in Table 3 . The demographic profiles show that the majority (79\%) of the participants were over 50 years old and had more than 15 years of working experiences. All of them also fulfilled the required educational qualification.

The AHP analysis of the Barriers and Sub-Barriers of the supply chain implementation in the Malaysian automotive industry as outlined by Parmar \& Shah (2016) are explained in the three sections below i.e. 4.1) Formation of group Pair-Wise Comparison Matrices, 4.2) List of Priorities of Barriers and Sub-barriers, and 4.3) Discussion.

\subsection{Formation of group pair-wise comparison matrices}

As clarified earlier, multiple responses from the 14 practitioners presented in Pair-Wise Comparison Matrices were aggregated using the Geometric Means. Since the SuperDecisions software does not have the functionality to calculate the Geometric Means of Pair-Wise Comparisons, Microsoft Excel was used to compute them. Table 4 exhibits the aggregated Pair-Wise Comparison Matrix (PCM) for all the 14 practitioners on the 5 categories of Barriers, namely, Strategic barrier (C1), 2) Cultural barrier (C2), 3) Technological barrier (C3), 4) Individual barrier (C4), and 5) Organisational barrier (C5). Table 4 comprises entries from 10 pair-wise comparisons.

Table 5 presents the aggregated PCM for Sub-Barriers of the Strategic Barrier category. The Sub-Barriers are Unclear organisation objective (C11), Lack of top management commitment and support (C12), Low customer satisfaction index (C13), Lack of awareness about SCM (C14), Short-term decision-making perspectives (C15), Political instability ( $\mathrm{C}$ (6), and lack of resource and capability (C17). The table comprises 21 pair-wise comparisons.

The aggregated PCM for the Sub-Barriers of the Cultural Barrier (C2) which consists of Unwillingness to implement supply chain practice (C21), Unwillingness to share information among supply chain partners (C22) and Mistrust among employees and supply chain partners (C23) is displayed in Table 6.

The aggregated PCM for Sub-Barriers of the Technological Barrier (C3) i.e. Lack of information technology (C31) and Poor ICT structure (C32) is displayed in Table 7.

Table 8 exhibits the aggregated PCM (15 pair-wise comparisons) for the Sub-Barriers of the Individual Barrier (C4) which comprises lack of education of employee and supplier's employee (C41), Resistance to change (C42), Lack of motivation and employee involvement (C43), Unawareness among society about social practices (C44), Lack of awareness about environment and other sustainability issues (C45), and lack of necessary tools, management skills and knowledge (C46). 
Table 3. Profile of the respondents.

\begin{tabular}{|c|c|c|}
\hline Demographic Profile & Frequency & Percentage \\
\hline \multicolumn{3}{|l|}{ Gender } \\
\hline - Male & 11 & 79.00 \\
\hline - Female & 3 & 21.00 \\
\hline \multicolumn{3}{|l|}{ Race } \\
\hline - Malay & 9 & 64.00 \\
\hline - Chinese & 3 & 22.00 \\
\hline - Indian & 2 & 14.00 \\
\hline - Others & - & - \\
\hline \multicolumn{3}{|l|}{ Age Group } \\
\hline - 21 - 30 years & - & - \\
\hline - 31 - 40 years & - & - \\
\hline - 41 - 50 years & 3 & 21.00 \\
\hline - 51 year and above & 11 & 79.00 \\
\hline \multicolumn{3}{|l|}{ Educational level } \\
\hline - Certificate/Diploma & - & - \\
\hline - Bachelors & 10 & 71.00 \\
\hline - Master's & 4 & 29.00 \\
\hline - $\mathrm{PhD}$ & - & \\
\hline \multicolumn{3}{|l|}{ Type of employment } \\
\hline - Public sector & - & - \\
\hline - Private sector & 14 & 100.00 \\
\hline - Others & - & - \\
\hline \multicolumn{3}{|l|}{ Working experience } \\
\hline - 1 - 5 years & - & - \\
\hline - 6 - 10 years & - & - \\
\hline - 10 - 15 years & 2 & 14.00 \\
\hline - 15 years and above & 12 & 86.00 \\
\hline \multicolumn{3}{|l|}{ Position in the organisation } \\
\hline - Executive & - & - \\
\hline - Assistant Manager & 3 & 21.40 \\
\hline - Manager & 5 & 35.80 \\
\hline - Senior Manager & 6 & 42.80 \\
\hline
\end{tabular}

Table 4. The aggregated PCM for the five categories of Barriers.

\begin{tabular}{cccccc}
\hline & $C 1$ & $C 2$ & $C 3$ & $C 4$ & $C 5$ \\
\hline$C 1$ & 1 & 4.6089 & 1.1421 & 1.0240 & 0.3109 \\
$C 2$ & 1 & 0.5583 & 0.3370 & 0.3544 \\
$C 3$ & & 1 & 3.5410 & 0.7036 \\
$C 4$ & & & 1 & 0.4019 \\
$C 5$ & & & & 1 \\
\hline
\end{tabular}

Table 5. The aggregated PCM for the Sub-Barriers of the Strategic Barrier (C1).

\begin{tabular}{|c|c|c|c|c|c|c|c|}
\hline & $C 11$ & $C 12$ & $C 13$ & $C 14$ & $C 15$ & $C 16$ & $C 17$ \\
\hline C11 & 1 & 1.0899 & 1.7172 & 1.3034 & 0.8726 & 1.1867 & 1.1778 \\
\hline C12 & & 1 & 1.5163 & 0.6127 & 0.8521 & 1.6635 & 1.1874 \\
\hline $\mathrm{C} 13$ & & & 1 & 04672 & 0.4921 & 1.0771 & 0.4811 \\
\hline $\mathrm{C} 14$ & & & & 1 & 1.6816 & 1.0633 & 0.9284 \\
\hline C15 & & & & & 1 & 1.4602 & 0.3464 \\
\hline C16 & & & & & & 1 & 0.5148 \\
\hline $\mathrm{C} 17$ & & & & & & & 1 \\
\hline
\end{tabular}


Table 6. The aggregated PCM for the Sub-Barriers of the Cultural Barrier (C2).

\begin{tabular}{cccc}
\hline & $C 21$ & $C 22$ & $C 23$ \\
\hline$C 21$ & 1 & 0.8120 & 0.9107 \\
$C 22$ & & 1 & 1.4729 \\
$C 23$ & & & 1 \\
\hline
\end{tabular}

Table 7. The aggregated PCM for the Sub-Barriers of the Technological Barrier (C3).

\begin{tabular}{cccc}
\hline & C31 & C32 & \\
\hline C31 & 1 & 2.4064 & 1 \\
C32 & & 1 & 1 \\
\hline
\end{tabular}

Table 8. The aggregated PCM for the Sub-Barriers of the Individual Barrier (C4).

\begin{tabular}{ccccccc}
\hline & C41 & C42 & C43 & C44 & C45 & C46 \\
\hline C41 & 1 & 1.6506 & 0.7579 & 0.6424 & 05031 & 0.3059 \\
C42 & & 1 & 0.4165 & 1.1240 & 0.8418 & 0.3464 \\
C43 & & 1 & 4.47716 & 3.2624 & 0.4026 \\
C44 & & & 1 & 0.3383 & 0.7553 \\
C45 & & & & 1 & 0.9370 \\
C46 & & & & & & 1 \\
\hline
\end{tabular}

Table 9. The aggregated PCM for Sub-Barriers of the Organisational Barrier (C5).

\begin{tabular}{ccccccc}
\hline & C51 & C52 & C53 & C54 & C55 & C56 \\
\hline C51 & 1 & 5.0137 & 4.0229 & 3.3584 & 1.9520 & 1.6377 \\
C52 & & 1 & 0.6416 & 0.7373 & 0.2162 & 0.3531 \\
C53 & & 1 & 0.3757 & 0.2867 & 0.3795 \\
C54 & & & 1 & 2.2906 & 1.5943 \\
C55 & & & & 1 & 2.9451 \\
C56 & & & & & 1 \\
\hline
\end{tabular}

Finally, the aggregated PCM for the Sub-Barriers of the Organisational Barrier (C5) is shown in Table 9 (15 pair-wise comparisons). Note that in this case the Sub-Barriers are the following: Lack of financial gain (C51), Lack of framework (C52), Lack of measurement system (C53), Lack of proper organisational structure to create and share knowledge (C54), Lack of inter-organisational cooperation and coordination (C55), and Lack of infrastructure (C56).

\subsection{List of priorities for Barriers and Sub-Barriers}

This section presents priorities of the five categories of Barriers (refer to Table 10) and the local and global priorities of the Sub-Barriers of the five categories of Barriers (refer to Table 11). The priorities were calculated using the SuperDecisions software version 2.8. The SuperDecisions model of the present problem is shown in Figure 4 .

It is to be noted that robustness of any weighting scheme is an important issue. Evidently, weight of a specific criterion will change if some existing criterion is dropped from the criteria set, however, rank of the criterion may remain the same. On the other hand, if new criterion is added to the existing set of criteria, then rank reversal can also happen for certain criterion. In the present work, in the absence of alternatives, the weights of the Barriers and Sub-Barriers are determined by taking inputs from relevant respondents. As expected, decrease or increase of number of respondents may change the quantum of weights of the barriers though it is premised that there will not be significant change in the ranks that they hold. 
Table 10. Priorities of the five categories of Barriers.

\begin{tabular}{ccc}
\hline Barrier category & Priority & Rank \\
\hline$\bullet$ Strategic Barrier (C1) & 0.1973 & 3 \\
$\bullet$ Cultural Barrier (C2) & 0.0774 & 5 \\
$\bullet$ Technological Barrier (C3) & 0.2366 & 2 \\
$\bullet$ Individual Barrier (C4) & 0.1409 & 4 \\
$\bullet$ Organisational Barrier (C5) & 0.3477 & 1 \\
\hline
\end{tabular}

Table 11. Local and global priorities of the Sub-Barriers of the five categories of Barriers.

\begin{tabular}{|c|c|c|c|}
\hline Barrier & Local priority & $\begin{array}{l}\text { Global } \\
\text { priority }\end{array}$ & Rank \\
\hline STRATEGIC BARRIER $(\mathrm{Cl})$ & 0.1973 & - & \\
\hline - Unclear organisation objective ( $\mathrm{C} 11)$ & 0.1605 & 0.0317 & 11 \\
\hline - Lack of top management commitment and support ( 12 ) & 0.1448 & 0.0286 & 13 \\
\hline - Low customer satisfaction index (C13) & 0.0869 & 0.0171 & 21 \\
\hline - Lack of awareness about SCM (C14) & 0.1708 & 0.0337 & 10 \\
\hline - Short-term decision-making perspectives (C15) & 0.1368 & 0.0270 & 14 \\
\hline - Political instability (C16) & 0.1051 & 0.0207 & 20 \\
\hline - Lack of resource and capability ( $\mathrm{C} 17)$ & 0.1950 & 0.0385 & 8 \\
\hline \multicolumn{4}{|l|}{$C R=0.03$} \\
\hline CULTURAL BARRIER (C2) & 0.0775 & & \\
\hline - Unwillingness to implement supply chain practice (C21) & 0.2981 & 0.0231 & 17 \\
\hline - Unwillingness to share information among supply chain partners (C22) & 0.4024 & 0.0312 & 12 \\
\hline - Mistrust among employees and supply chain partners (C23) & 0.2995 & 0.0232 & 16 \\
\hline \multicolumn{4}{|l|}{$\mathrm{CR}=0.01$} \\
\hline TECHNOLOGICAL BARRIER (C3) & 0.2366 & & \\
\hline - Lack of information technology (C31) & 0.7067 & 0.1672 & 1 \\
\hline - Poor 1CT structure (C32) & 0.2933 & 0.0694 & 4 \\
\hline \multicolumn{4}{|l|}{$C R=0.00$} \\
\hline INDIVIDUAL BARRIER (C4) & 0.1409 & & \\
\hline - Lack of education to employee and supplier employee (C41) & 0.1033 & 0.0145 & 22 \\
\hline - Resistance to change (C42) & 0.0924 & 0.0130 & 24 \\
\hline - Lack of motivation and employee involvement (C43) & 0.2595 & 0.0366 & 9 \\
\hline - Unawareness among society about social practices (C44) & 0.1006 & 0.0142 & 23 \\
\hline - Lack of awareness about environment and other sustainability issues (C45) & 0.1684 & 0.0237 & 14 \\
\hline - Lack of necessary tools, management skills and knowledge ( $\mathrm{C} 46$ ) & 0.2757 & 0.0388 & 7 \\
\hline \multicolumn{4}{|l|}{$C R=0.10$} \\
\hline ORGANISATIONAL BARRIER (C5) & 0.3477 & & \\
\hline - Lack of financial gain (C51) & 0.3349 & 0.1164 & 2 \\
\hline - Lack of framework (C52) & 0.0622 & 0.0216 & 19 \\
\hline - Lack of measurement system (C53) & 0.0661 & 0.0229 & 18 \\
\hline - Lack of proper organisational structure to create and share knowledge (C54) & 0.1908 & 0.0663 & 5 \\
\hline - Lack of inter-organisational cooperation and coordination (C55) & 0.2107 & 0.0732 & 3 \\
\hline - Lack of infrastructure (C56) & 0.1352 & 0.0470 & 6 \\
\hline $\mathrm{CR}=0.08$ & & & \\
\hline
\end{tabular}

\subsection{Discussion}

This section describes the prioritised list of the Barriers of SCM implementation in the Malaysian automotive industry. The ranks are generated from the local and global priority values displayed in Table 10 and Table 11. It shows that Organisational Barrier (C5) is ranked as the top-most in importance, followed by Technological Barrier (C3) and Strategic Barrier (C1). The least two important categories of Barriers ranked by all the practitioners are Individual Barrier (C4) and Cultural Barrier (C5).

Overall, the finding of this study is aligned with the work of Laforet (2013) who discovered that organisation is one of the main factors that hinder effective implementation of SCM. Since the main barrier spirals down to 


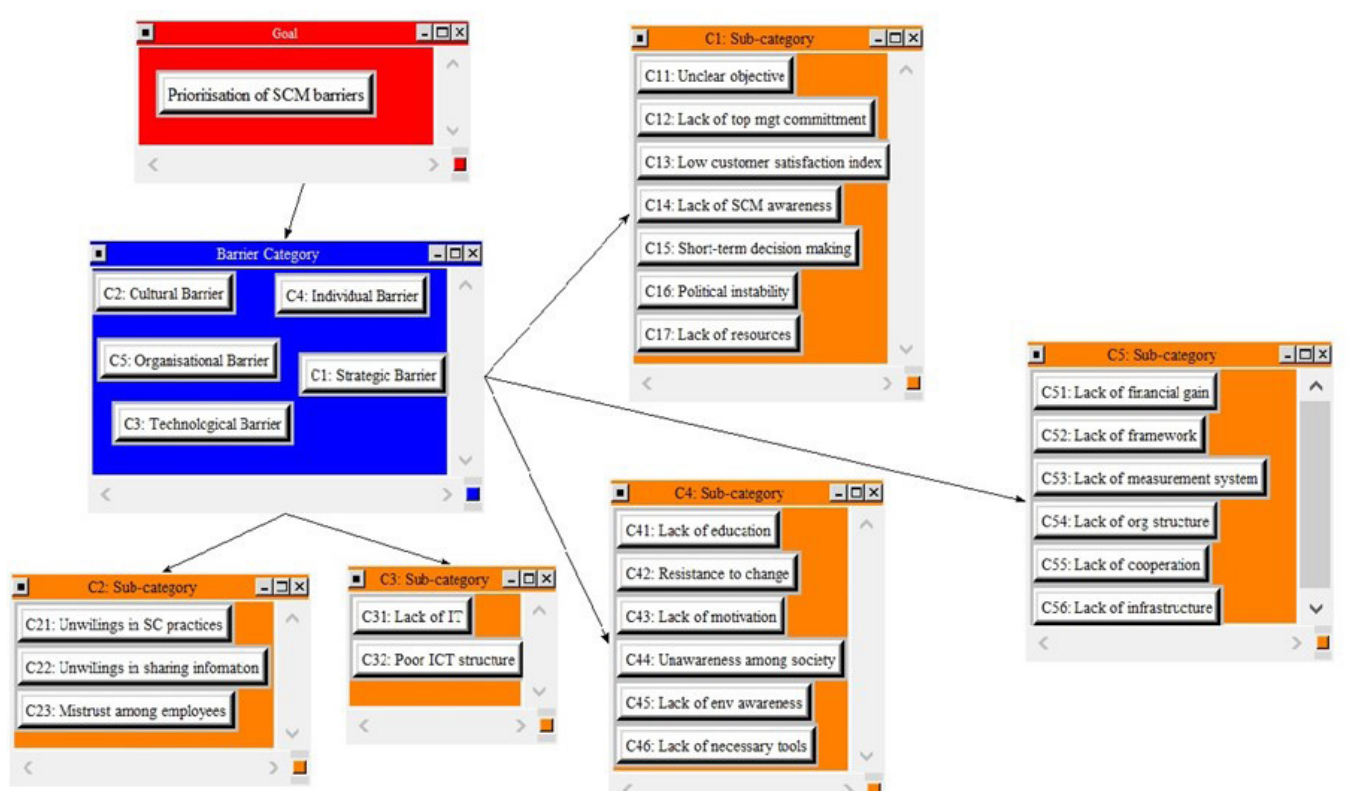

Figure 4. The SuperDecisions model of the Barriers' prioritisation problem.

organisation, the focus of the Malaysian automotive industry should be to make an effective blend of alignment and flexibility within the organisation. The Malaysian automotive industry needs to strengthen its internal capacity particularly in its financial as well as inter-organisational cooperation and coordination to ensure its sustainability in this highly competitive environment. Furthermore, the Organisational Barrier (C5) needs to be properly addressed so that Malaysia can maintain its position as the third largest automobile producer in Southeast Asia after Thailand and Indonesia.

Technological Barrier (C3) is the second critical barrier that is ranked by the respondents for the present study which was also revealed by the work of Delic et al. (2019). The researchers of that study stressed that one of the most convincing approaches in ensuring effective implementation of the organisations' supply chain activities is by adopting new technologies. As such the Malaysian automotive industry should introduce strong initiatives in addressing matters related to technological barrier. This is due to the fact that managing the supply chain in this current era is more complex and challenging due to e-commerce and globalisation. Moreover, with an increasing competition among businesses and external pressure from customers, the supply chain technology integration can be the key to overcoming several challenges in SCM.

The barrier that is at the third rank of importance as perceived by the respondents in this study is Strategic Barrier (C1). This finding is corroborated with the findings of lee (2021) whereby automotive companies in Malaysia should prioritise their resources in addressing the Strategic Barrier (C1). Lee (2021) declares that strategies of SCM have major impacts on organisations including the automotive industry. Addressing the Strategic Barrier (C1) enables the Malaysian automotive industry to create a clear vision and direction for the organisation. Clearer vision and direction will drive the organisation's top management to manage their resources effectively. It will finally ensure effective implementation of SCM.

Table 11 provides the ranks of the Sub-Barriers. For the top-most important barrier which is Organisational Barrier (C5), it is observed that Lack of financial gain (C51), Lack of inter-organisational cooperation and coordination (C55) and lack of proper organisational structure to create and share knowledge (C54) were ranked first, second and third, respectively. For the second most critical barrier, namely Technological Barrier (C3), in terms of criticality the Sub-Barriers are Lack of information technology (C31) and Poor ICT structure (C32). For the Strategic Barrier (C1), the top three Sub-Barriers are Lack of resource and capability (C17), Lack of awareness about SCM (C14), and Unclear organisation objective (C11).

As mentioned above, the Individual barrier category emerged as the fourth critical barrier for SCM implementation in the Malaysian automotive industry. For this category, the Sub-Barriers that received the top three ranks are Lack of necessary tools, Management skills and knowledge (C46), Lack of motivation and employee involvement (C43), and Lack of awareness about environment and other sustainability issues (C45). 
It also can be seen from Table 11 that Unwillingness to share information among the supply chain partners (C22), Mistrust among employees and supply chain partners (C23) and Unwillingness to implement supply chain practice (C21) are the first, second and third Sub-Barriers for the Cultural Barrier category (C2).

Implementing SCM may need adjustment to new systems, which may incur substantial expenses. For this reason, organisations find difficulty to adopt it in the first place. Organisations however, often focus on the initial costs of implementation and fail to see the long-term benefits of new and effective system of SCM. The decisions to adopt new SCM's systems are often influenced by an assessment of the high expenses required against the advantages that will be obtained (Zhu and Geng, 2013; Nhemachena \& Murimbika, 2018). This explains why lack of financial gain has been found to be one of the critical barriers in the present study. In addition, the execution of an effective SCM implementation should be based on internal collaborative efforts between departments and employees. As Savino \& Batbaatar (2015) said, it is possible to increase synergy, productivity and reduce lead time by having a strong collaboration between employers and employees. When the internal organisation is supportive and proactive, it facilitates adoption of new SCM's systems and thus improve its sustainability performance (Prasad et al., 2020).

The openness in sharing information and knowledge allows related parties including suppliers and employees in the supply chain to respond faster. Bennett \& Klug (2012) found that making partnership and information exchange through structured supplier networks and use of particular technologies have contributed to enhanced collaboration in automotive industry. Through the exchange and sharing of information, an organisation can expedite the flow of information in the supply chain. Improved productivity and efficiency is another advantage, since information sharing lessens the ambiguity and therefore minimises the need for security stocks (George \& Pillai, 2019).

If the supply chain concepts and practices are to be applied successfully, management commitment and support should be taken into consideration (Luthra et al., 2016). To effectively manage the supply chain activities, managers must have an exhaustive understanding plus the ability to monitor related processes and activities in the supply chain ranging from sourcing, logistics, manufacturing and finally on retail distribution to consumers (Olson, 2017). Alfalla-Luque et al. (2015) also found that employees' commitment influences organisation performance through the supply chain integration.

To address the problem of environment and sustainability, a certain degree of competence is required to integrate social and environmental practices into the Malaysian automotive industry (Menon \& Ravi, 2021). Seminars and campaigns, for example, should be organised to inculcate and instil knowledge pertaining to the subject. According to studies conducted by Al Zaabi et al. (2013) as well as Kumar et al. (2013) the effectiveness of SCM implementation can be enhanced by introducing sustainable practices among key partners in the supply chain.

Next, the 24 Sub-Barriers for all the five identified category of Barriers are arranged according to their corresponding global priorities, as shown in Table 12.

From Table 12, it is observed that the top five most critical Sub-Barriers among the full list of 24 Sub-Barriers as ranked by all the practitioners on SCM implementation in the Malaysian automotive industry are as follows:

1. Lack of information technology

2. Lack of financial gain

3. Lack of inter-organisational cooperation and coordination

4. Poor ICT structure

5. Lack of proper organisational structure to create and share knowledge.

It is also noted that the above five most critical Sub-Barriers belong to two categories of barriers, namely the Organisational and Technological barriers. In contrast, the least critical five Sub-Barriers for the SCM implementation in the Malaysian automotive industry are the following:

1. Political instability

2. Low customer satisfaction index

3. Lack of education to employee and supplier employee

4. Unawareness among society about social practices

5. Resistance to change 
Table 12. Ranking for the Sub-Barriers according to global priority.

\begin{tabular}{|c|c|c|c|c|}
\hline No. & Barrier & Barrier category & Global priority & Rank \\
\hline 1 & Lack of information technology & Technological & 0.1672 & 1 \\
\hline 2 & Lack of financial gain & Organisational & 0.1164 & 2 \\
\hline 3 & Lack of inter-organisational cooperation and coordination & Organisational & 0.0732 & 3 \\
\hline 4 & Poor 1CT structure & Technological & 0.0694 & 4 \\
\hline 5 & Lack of proper organisational structure to create and share knowledge & Organisational & 0.0663 & 5 \\
\hline 6 & Lack of infrastructure & Organisational & 0.047 & 6 \\
\hline 7 & Lack of necessary tools, management skills and knowledge & Individual & 0.0388 & 7 \\
\hline 8 & Lack of resource and capability & Strategic & 0.0385 & 8 \\
\hline 9 & Lack of motivation and employee involvement & Individual & 0.0366 & 9 \\
\hline 10 & Lack of awareness about SCM & Strategic & 0.0337 & 10 \\
\hline 11 & Unclear organisation objective & Strategic & 0.0317 & 11 \\
\hline 12 & Unwillingness to share information among supply chain partners & Cultural & 0.0312 & 12 \\
\hline 13 & Lack of top management commitment and support & Strategic & 0.0286 & 13 \\
\hline 14 & Short-term decision-making perspectives (C15) & Strategic & 0.027 & 14 \\
\hline 15 & Lack of awareness about environment and other sustainability issues & Individual & 0.0237 & 15 \\
\hline 16 & Mistrust among employees and supply chain partners & Cultural & 0.0232 & 16 \\
\hline 17 & Unwillingness to implement supply chain practice & Cultural & 0.0231 & 17 \\
\hline 18 & Lack of measurement system & Organisational & 0.0229 & 18 \\
\hline 19 & Lack of framework & Organisational & 0.0216 & 19 \\
\hline 20 & Political instability & Strategic & 0.0207 & 20 \\
\hline 21 & Low customer satisfaction index & Strategic & 0.0171 & 21 \\
\hline 22 & Lack of education to employee and supplier employee & Individual & 0.0145 & 22 \\
\hline 23 & Unawareness among society about social practices & Individual & 0.0142 & 23 \\
\hline 24 & Resistance to change (C42) & Individual & 0.013 & 24 \\
\hline
\end{tabular}

The discussion above provides rich insights on the Barriers and Sub-Barriers that are hindering effective SCM implementation in the Malaysian automotive industry. Hence, the Malaysian automotive industry should concentrate primarily on overcoming these barriers particularly the barriers that were ranked as the first, second and third importance i.e. Organisational Barrier, Technological Barrier and Strategic Barrier. The Sub-Barriers of each identified Barrier provide detailed explanation on how the Malaysian automotive industry should prioritise their resources in addressing them. Any obstacle that prevents the Malaysian automotive industry from performing at its best level should be removed or avoided.

The main contribution of this research is that it has thoroughly analysed the critical barriers that need to be considered for an effective SCM implementation by prioritising the Barriers and Sub-Barriers for the Malaysian automotive industry. Since any organisation's resources are limited, it cannot implement all new policies or strategies simultaneously. In this regard, the prioritised list of Barriers and Sub-Barriers will be a useful guide to an automotive company on where to start from. This will help optimise resource utilisation for the company.

\section{Implications of the study}

Findings of the present study will enable managers in the Malaysian automotive industry to distinctly identify the Barriers that take place throughout the SCM implementation process, acknowledge their impact and proactively take action to resolve them. The Barriers are categorised and prioritised accordingly to offer managers rich insights of the Barriers that need to be addressed in the context of SCM implementation in the Malaysian automotive industry. Addressing the Barriers should be the top priority for managers in the Malaysian automotive industry to ensure that they are ahead of their competitors. This study is substantial as it allows related parties in the Malaysian automotive industry such as policy makers, Automobile Associations and automotive companies to accurately design strategies in addressing the Barriers for the betterment of the nation's automotive industry. Also, they should find ways to promote dialogue in various platforms that could spur mutual understanding between key partners of the supply chain. However, the most crucial action is that they need to strongly cooperate in developing and executing the policies to ensure that the issues on the identified Barriers and Sub-Barriers in the Malaysian automotive industry are resolved. 


\section{Conclusions}

Malaysia's automotive industry contributes significantly to her GDP. Since Supply Chain Management plays a crucial role in the automotive industry, like many other industries, adequate attention should be paid to boost the supply chain performance so that the industry can maintain its contribution to the country's GDP. Based on extant literature, the present work compiled a list of Barriers which prevent the supply chain in providing the optimum results. These Barriers are broadly termed as Strategic, Cultural, Technological, Individual, and Organisational Barriers. Each of these categories possesses actionable, more specific Barriers. However, the level of cruciality varies from Barrier to Barrier. Since the management resources are limited, hence the prioritised list of Barriers is also crucial so that the management can tackle the most disruptive Barriers first. Subsequently, to generate the prioritised list of Barriers, AHP was applied. Overall, it is observed that Technological and Organizational Barriers are the most crucial ones. Therefore, it is recommended that managers entrusted with looking after SCM activities in the Malaysian automotive industry should pay more attention to acquiring the latest, modern technology in managing SCM activities, in particular to install proper ICT infrastructure. It is also found that there should be greater inter-organisational cooperation and collaboration. Since Malaysia has a number of sizeable automotive companies, greater collaboration among them is deemed necessary. Managers too are also recommended to develop superior platforms for knowledge sharing. As for future research, further investigation can be carried out to capture the interaction and dependence among Barriers as well as Sub-Barriers by using the Analytic Network Process (ANP). In addition, it is recommended for future researchers to derive and prioritise possible alternatives (solutions) for the identified barriers and sub-barriers. Then sensitivity analysis can be applied to investigate the stability of ranks for the identified possible alternatives (solutions). Other popular methods of multicriteria analysis, namely Fuzzy AHP, DEMATEL. TOPSIS can also be applied to investigate the objective of this research from a different angle.

\section{Acknowledgements}

The authors would like to acknowledge Universiti Teknologi MARA (UiTM), Cawangan Selangor for providing grant namely Dana UiTM Cawangan Selangor (DUCS) to carry out the present research activities. The grant number is: GERAN DUCS 600 - UiTMSEL (Pl.5/4) (035/2018).

\section{References}

Adhikari, D. R. (2010). Human resource development (HRD) for performance management: The case of Nepalese organizations. International Journal of Productivity and Performance Management, 59(4), 306-324. http://dx.doi.org/10.1108/17410401011038883.

Agrawal, N., \& Kant, S. (2020) Supplier selection using fuzzy-AHP: a case study. In: I. Singh, P. Bajpai, K. Panwar (Eds.), Trends in manufacturing processes. Singapore: Springer. http://dx.doi.org/10.1007/978-981-32-9099-0_13.

Al Zaabi, S., Al Dhaheri, N., \& Diabat, A. (2013). Analysis of interaction between the barriers for the implementation of sustainable supply chain management. International Journal of Advanced Manufacturing Technology, 68(1-4), 895-905. http://dx.doi.org/10.1007/ s00170-013-4951-8.

Alfalla-Luque, R., Marin-Garcia, J. A., \& Medina-Lopez, C. (2015). An analysis of the direct and mediated effects of employee commitment and supply chain integration on organisational performance. International Journal of Production Economics, 162, 242-257. http:// dx.doi.org/10.1016/j.jpe.2014.07.004.

Aouadni, S., Aoudni, 1., \& Rebai, A. (2019). A systematic review on suppler selection and order allocation problems. Journal of Industrial Engineering International, 15(1), 5267-5289.

Baharudin, N., \& Jusoh, R. (2019). Implementation of target cost management in a non-environment. Qualitative Research in Accounting \& Management, 16(1), 35-59. http://dx.doi.org/10.1108/QRAM-02-2018-0017.

Balon, V., Sharma, A. K., \& Barua, M. K. (2016). Assessment of barriers in green supply chain management using ISM: a case study of the automotive industry in India. Global Business Review, 17(1), 116-135. http://dx.doi.org/10.1177/0972150915610701.

Bennett, D., \& Klug, F. (2012). Logistics supplier integration in the automotive industry. International Journal of Operations \& Production Management, 32(11), 1281-1305. http://dx.doi.org/10.1108/01443571211274558.

Bhat, K. S., \& Rajashekhar, J. (2009). An empirical study of barriers to TQM implementation in Indian industries. The TQM Magazine, 21(3), 261-272. http://dx.doi.org/10.1108/17542730910953031.

Charan, P., Shankar, R., \& Baisya, R. K. (2009). Modelling the barriers of supply chain performance measurement system implementation in the Indian automotive supply chain. Interntional Journal of Logistics Systems and Management, 5(6), 614-630. http://dx.doi. org/10.1504/1JLSM.2009.024794.

Chopra, S., \& Meindl, P. (2007). Supply chain management: strategy, planning and operation (5th ed.). New Jersey: Pearson Education.

Chopra, S., \& Meindl, P. (2010). Supply chain management. New Jersey: Pearson Education.

Delic, M., Eyers, D. R., \& Mikulic, J. (2019). Additive manufacturing: empirical evidence for supply chain integration and performance from the automotive industry. Supply Chain Management, 24(5), 604-621. http://dx.doi.org/10.1108/SCM-12-2017-0406. 
Drohomeretski, E., Gouvea da Costa, S., \& Lima, E. P. (2014). Green supply chain management. Journal of Manufacturing Technology Management, 25(8), 1105-1134. http://dx.doi.org/10.1108/JMTM-06-2014-0084.

Fawcett, S. E., McCarter, M. W., Fawcett, A. M., Webb, G. S., \& Magnan, G. M. (2015). Why supply chain collaboration fails: the socio-structural view of resistance to relational strategies. Supply Chain Management, 20(6), 648-663. http://dx.doi.org/10.1108/ SCM-08-2015-0331.

Feizabadi, J., \& Alibakhshi, S. (2021). Synergistic effect of cooperation and coordination to enhance the firm's supply chain adaptability and performance. Benchmarking, 29(1), 1-36.

Fernando, Y., Walters, T., Ismail, M. N., Seo, Y. W., \& Kaimasu, M. (2018). Managing project success using project risk and green supply chain management. International Journal of Managing Projects in Business, 11(2), 332-365. http://dx.doi.org/10.1108/ IJMPB-01-2017-0007.

Flavia, C. S., Fabio, Y. S., Jose, C. B., Andre, F. L., \& Mario, R. S. (2017). Barriers to green supply chain management in the automotive industry. Journal of Business and Management, 58(2), 149-162.

George, J., \& Pillai, V.M. (2019). A study of factors affecting supply chain performance. Journal of Physics: Conference Series, 1355 , 012018. doi:10.1088/1742-6596/1355/1/012018.

Gorane, S. J., \& Kant, R. (2015). Modelling the SCM implementation barriers. Journal of Modelling in Management, 10(2), $158-178$. http://dx.doi.org/10.1108/JM2-08-2012-0026.

Habidin, N. F., \& Mohd Yusof, S. (2013). Critical success factors of Lean Six Sigma for the Malaysian automotive industry. International Journal of Lean Six Sigma, 4(1), 60-82. http://dx.doi.org/10.1108/20401461311310526.

Habidin, N. F., Hashim, S., Fuzi, N. M., \& Salleh, M. 1. (2018). Total productive maintenance, Kaizen event, and performance. International Journal of Quality \& Reliability Management, 35(9), 1853-1867. http://dx.doi.org/10.1108/lJQRM-11-2017-0234.

Islam, R. (2010). Critical success factors of the nine challenges in Malaysia’s vision 2020. Socio-Economic Planning Sciences, 44(4), 199-211. http://dx.doi.org/10.1016/j.seps.2010.07.002.

Islam, R., \& Anis, A., (2018). Prioritisation of internal and external barriers for supply-chain implmentation in manufacturing companies: A Malaysian erspective. In V. A. P. Salomon (Ed.), Multi-criteria methods and techniques applied to supply chain management. London: Intech Open Limited.

Kamaruddin, N. K., \& Udin, Z. M. (2009). Supply chain technology adoption in Malaysian automotive suppliers. Journal of Manufacturing Technology Management, 20(3), 385-403. http://dx.doi.org/10.1108/17410380910936819.

Korpela, J., \& Lehmusvaara, A. (1999). A customer oriented approach to warehouse network evaluation and design. International Journal of Production Economics, 59(1-3), 135-146. http://dx.doi.org/10.1016/S0925-5273(98)00096-6.

Korpela, J., Lehmusvaara, A., \& Tuominen, M. (2001). An analytic approach to supply chain development. International Journal of Production Economics, 71(1-3), 145-155. http://dx.doi.org/10.1016/S0925-5273(00)00114-6.

Krejčí, J., \& Stoklasa, J. (2018). Aggregation in the Analytic Hierarchy Process: why weighted geometric mean should be used instead of weighted arithmetic mean. Expert Systems with Applications, 114, 97-106. http://dx.doi.org/10.1016/j.eswa.2018.06.060.

Kumar, S., Luthra, S., \& Haleem, A. (2013). Customer involvement in greening the supply chain: an interpretive structural modeling methodology. Journal of Industrial Engineering International, 9, 6. http://dx.doi.org/10.1186/2251-712X-9-6.

Laforet, S. (2013). Organisational innovation outcomes in SMEs: effects of age, size and sector. Journal of World Business, 48(4), 490502. http://dx.doi.org/10.1016/j.jwb.2012.09.005.

Lee, R. (2021). The effect of supply chain management strategy on operational and financial performance. Sustainability, 13(9), 5138. http://dx.doi.org/10.3390/su13095138.

Lee, Y.-C., Chu, P.-Y., \& Tseng, H.-L. (2011). Corporate performance of ICT-enabled business process re-engineering. Industrial Management \& Data Systems, 111(5), 735-754. http://dx.doi.org/10.1108/02635571111137287.

Lima-Junior, F. R., \& Carpinetti, L. C. R. (2017). Quantitative models for supply chain performance evaluation: a literature review. Computers \& Industrial Engineering, 113, 333-346. http://dx.doi.org/10.1016/j.cie.2017.09.022.

Luthra, S., Mangla, S. K., Xu, L., \& Diabat, A. (2016). Using AHP to evaluate barriers in adopting sustainable consumption and production initiatives in a supply chain. International Journal of Production Economics, 181, 342-349. http://dx.doi.org/10.1016/j.jpe.2016.04.001.

Malaysian Automotive Association. (2021). Sales \& production statistics. Retrieved in 12 May 2021, from http://www.maa.org.my/ statistics.html

Masella, C., \& Rangone, A. (2000). A contingent approach to the design of vendor selection systems for different types of co-operative customer/supplier relationships. International Journal of Operations \& Production Management, 20(1), 70-84. http://dx.doi. org/10.1108/01443570010287044.

Mastrocinque, E., Javier Ramírez, F., Honrubia-Escribano, A., Duc, T., \& Pham, D. T. (2020). An AHP-based multi-criteria model for sustainable supply chain development in the renewable energy sector. Expert Systems with Applications, 150, 113321. http://dx.doi. org/10.1016/j.eswa.2020.113321.

Meehan, J., \& Muir, L. (2008). SCM in Merseyside SMEs: benefits and barriers. The TQM Journal, 20(3), 223-232. http://dx.doi. org/10.1108/17542730810867245.

Menon, R. R., \& Ravi, V. (2021). Analysis of barriers of sustainable supply chain management in electronics industry: an interpretive structural modelling approach. Cleaner and Responsible Consumption, 3, 100026. http://dx.doi.org/10.1016/j.clrc.2021.100026.

Mohd, S. N. A., Kasolang, S., \& Jaafar, A. (2011). Reviewing study of developing an integrated TQM with LM framework model in Malaysian automotive industy. The TQM Journal, 24(5), 399-417. http://dx.doi.org/10.1108/17542731211261566.

Nazir, N. M., \& Shavarebi, K. (2019). A review of global automotive industry's competitive strategies. World Journal of Science and Sustainable Development, 16(4), 170-183. http://dx.doi.org/10.1108/WJSTSD-10-2018-0060.

Nhemachena, C., \& Murimbika, M. (2018). Motivations of sustainable entrepreneurship and their impact of enterprise performance in Gauteng province, South Africa. Business Strategy and Development, 1(2), 115-127. http://dx.doi.org/10.1002/bsd2.16. 
Olson, D. L. (2017). View of IJPR contributions to knowledge management in supply chains. International Journal of Production Research, 56(1-2), 733-742.

Parmar, V., \& Shah, H. G. (2016). A literature review on supply chain management barriers in manufacturing organisation. International Journal of Engineering Development and Research, 4(1), 26-42.

Prasad, D. S., Pradhan, R. P., Gaurav, K., \& Sabat, A. K. (2020). Critical success factors of sustainable supply chain management and organizational performance: an exploratory study. Transportation Research Procedia, 48, 327-344. http://dx.doi.org/10.1016/j. trpro.2020.08.027.

Ravi, V., Shankar, R., \& Tiwari, M. K. (2005). Productivity improvement of a computer hardware supply chain. International Journal of Productivity and Performance Management, 54(4), 239-255. http://dx.doi.org/10.1108/17410400510593802.

Saaty, T. L. (1980). The analytic hierarchy process. New York: McGraw-Hill.

Saaty, T. L. (1990). How to make a decision: The Analytic Hierarchy Process. European Journal of Operational, 48(1), 9-26. http:// dx.doi.org/10.1016/0377-2217(90)90057-l.

Sadi, M. A., \& Al-Dubaisi, A. H. (2008). Barriers to organisational creativity: the marketing executive, perspective in Saudi Arabia. Journal of Management Development, 276), 574-599. http://dx.doi.org/10.1108/02621710810877839.

Savino, M. M., \& Batbaatar, E. (2015). Investigating the resources for Integrated Management Systems within resource-based and contingency perspective in manufacturing firms. Journal of Cleaner Production, 104, 392-402. http://dx.doi.org/10.1016/j.jclepro.2015.04.115.

Tahiri, F., Osman, M. R., Ali, A., \& Yusoff, M. R. (2008). A review of supplier selection methods in manufacturing industries. Warasan Technology Suranaree, 15(3), 201-208.

Tramarico, C. L., Mizuno, D., Salomon, V. A. P., \& Marins, F. A. S. (2015). Analytic hierarchy process and supply chain management: a bibliometric study. Procedia Computer Science, 55, 441-450. http://dx.doi.org/10.1016/j.procs.2015.07.005.

Tsinidou, M., Gerogiannis, V., \& Fitsilis, P. (2010). Evaluation of the factors that determine quality in higher education: an empirical study. Quality Assurance in Education, 18(3), 227-244. http://dx.doi.org/10.1108/09684881011058669.

Zhang, W., \& Wu, X. (2013). The importance of Supply Chain Management. International Journal of Business and Social Science, 4(16), 279-282.

Zhou, Y., Xu, L., \& Muhammad Shaikh, G. (2019). Evaluating and prioritizing the green supply chain management practices in pakistan: based on delphi and Fuzzy AHP approach. Symmetry, 11(11), 1346. http://dx.doi.org/10.3390/sym11111346.

Zhu, Q., \& Geng, Y. (2013). Drivers and barriers of extended supply chain practices for energy saving and emission reduction among Chinese manufacturers. Journal of Cleaner Production, 40, 6-12. http://dx.doi.org/10.1016/j.jclepro.2010.09.017. 